\title{
BEBERAPA KEUNIKAN SEBAGAI LANDASAN PENETAPAN OUTSTANDING UNIVERSAL VALUES (OUV) DALAM RANGKA MEWUJUDKAN KOTA LAMA SEMARANG SEBAGAI WORLD HERITAGE CITY
}

\author{
Eko Punto Hendro \\ Fakultas Ilmu Budaya \\ Universitas Diponegoro Semarang \\ email: eko.ipung@gmail.com
}

\begin{abstract}
Abstrak: Artikel ini bertujuan untuk mempelajari dan meneliti OUV (Outstanding Universal Values) di Kota Tua Semarang, sebagai salah satu persyaratan yang diajukan pemerintah untuk menjadikan Kota Tua Semarang sebagai warisan dunia UNESCO. Kriteria OUV menjadi contoh utama dari jenis bangunan, komposisi arsitektur atau teknologi, atau lansekap yang menggambarkan tahapan signifikan dalam sejarah manusia. Metode penelitian adalah observasi, heuristik, studi pustaka dan dijelaskan secara diskriptif.

Dari peta masa lalu Semarang diketahui bahwa keberadaan Kota Tua Semarang adalah pusat kota yang berada di bawah kendali VOC, yang dikelilingi oleh pemukiman (desa) dari berbagai bangsa dan etnis. Ini terkait dengan salah satu dari 10 kriteria kriteria OUV yang ditetapkan oleh UNESCO, yang mencerminkan pertukaran nilai-nilai mulia dari manusia, dalam rentang waktu atau dalam lingkup budaya dunia, arsitektur, teknologi, seni monumental, perencanaan kota atau desain lanskap.
\end{abstract}

Kata Kunci : Semarang, warisan dunia, OUV, tata kota

Abstract: This article will aim to study and examine OUV (Outstanding Universal Values) in the Semarang Old Town, as one of the requirements should the government propose the Semarang Old Town as a world heritage to UNESCO. OUV Criteria are prime examples for the type of building, the composition of architecture or technology, or landscape which illustrates significant stages in human history. The research methodology is observation, heuristic, literature study and qualitative.

From the old map of Semarang past, Semarang Old Town was recognized as the city center which is under the control of VOC, surrounded by settlements (villages) of various nationalities and ethnics. It relates to one of the 10 criteria OUV criteria set by UNESCO, which reflects an exchange of the noble values of human beings, in a span of time or within the scope of world culture, the architecture, technology, monumental arts, town-planning or landscape design.

Keywords : Semarang, world heritage, OUV, landscape

\section{Pendahuluan}

\section{A. Latar Belakang}

Kota Lama Semarang merupakan kawasan bekas kota tua di Semarang yang sangat unik. Permasalahannya sudah sejak lama bangunan-bangunan kuno di Kawasan Kota Lama Semarang dilindungi dengan peraturan daerah dan undang-undang tentang cagar budaya. Namun hingga kini masih banyak bangunan yang tidak terawat, rusak, bahkan ada yang roboh dengan sendirinya. Beberapa bangunan memang sudah dikonservasi dengan baik misalnya Gereja Blenduk, Gereja Gedangan dan Restoran Ikan Bakar Cianjur. Namun banyak pula bangunan yang direnovasi pemiliknya tetapi menyalahi aturan yang berlaku dengan merubah atau mengganti bagian-bagian bangunan.
Banyak kalangan yang mengharapkan Kawasan Kota Lama Semarang ini eksis sebagai kawasan konservasi, dengan bangunan-bangunan kuno yang terawat dan berfungsi dengan baik. Sebagai contoh dari hasil observasi, bahwa pemanfaatan bangunan untuk restoran Ikan Bakar Cianjur yang menyajikan menu utamanya makanan ikan bakar air tawar. Pengelola restoran ini telah merawat dan mempercantik bangunan kuno miliknya tanpa merubah bentuk aslinya, maka para pengunjung juga sangat senang dan menikmatinya, baik makanannya maupun tempatnya. Gereja Blenduk dan Gereja Gedangan, juga merupakan bangunan yang sangat kuno yang benar-benar dirawat oleh umatnya. Bangunan kuno akan sangat cantik dan unik apabila benar-benar dirawat, dan akan melebihi kecantikan bangunan yang baru. 
Dari urian di atas, kiranya diperlukan menangani Kota Lama Semarang melalui pengembangan konsep ataupun model konservasi kawasan, yaitu merupakan konsep penataan, pelestarian, dan pengembangan kawasan, dan tentu saja merupakan salah satu landasan budaya bagi perencanaan dan pengembangan kota, dan selanjutnya sangat potensial sebagai aset wisata dan sejarah kota (UU No. 11 Th 2010 Tentang Cagar Budaya).

Konservasi kawasan adalah suatu kegiatan yang diawali dengan penetapan kawasan sebagai kawasan cagar budaya yang terdiri dari beberapa situs, diikuti kemudian dengan kegiatan pelestarian dan pengembangan. Penetapan kawasan cagar budaya di Indonesia dapat dilakukan secara berperingkat, mulai dari peringkat kota/kabupaten, peringkat provinsi, peringkat nasional, hingga peringkat internasional, tergantung potensi dan kepentingannya. Melihat keunikan dari Kawasan Kota Lama Semarang, maka kawasan ini berpotensi ditetapkan sebagai kawasan berperingkat nasional, bahkan berperingkat internasional. Sebagai bukti, saat ini organisasi internasional bidang pendidikan dan kebudayaan dunia UNESCO memberikan peluang terhadap kawasan Kota Lama Semarang menjadi kawasan yang berstatus sebagai warisan dunia (world heritage). Hal ini ditindaklanjuti oleh Pemerintah Indonesia dengan memasukkan Kawasan Kota Lama Semarang ke dalam daftar warisan dunia (tentative list of world heritage), yang artinya diberikan waktu kepada Kota Lama Semarang untuk berbenah menata diri melakukan kegiatan konservasi secara komprehensif, untuk kemudian dapat dinominasikan sebagai Warisan Budaya Dunia dan ditetapkan melalui sidang World Heritage Commitee.

Kawasan cagar budaya di Indonesia yang belum lama ditetapkan pada tanggal 29 Juni 2012 dalam sidang ke-36 Komite Warisan Dunia UNESCO di kota Saint Peterburg, Federasi Rusia, adalah sistem Pengairan Pertanian Subak di Bali sebagai Warisan Budaya Dunia telah disetujui dan ditetapkan. Penetapan sebagai Warisan Budaya Dunia ini disambut baik oleh masyarakat dan pemerintah Bali. Sesuai dengan pengajuannya, Subak di Bali yang memiliki luas sekitar 20.000 ha terdiri atas Subak yang berada di lima kabupaten, yaitu Kabupaten Bangli, Gianyar, Badung, Buleleng, dan Tabanan. Sebelumnya, pada tahun 2006 Situs Sangiran ditetapkan sebagai Warisan Dunia Situs Manusia Purba (Arbi, 2013).
Tulisan ini akan bertujuan untuk mencari dan mencermati OUV (Outstanding Universal Values) yang ada di Kota Lama Semarang, sebagai salah satu persyaratan pemerintah mengusulkan Kota Lama Semarang sebagai warisan dunia kepada UNESCO dengan kriteria OUV menjadi contoh utama suatu tipe bangunan, gubahan arsitektur atau teknologi, atau lansekap yang menggambarkan tahapan yang penting dalam sejarah manusia. Adapun tujuan khusus penelitian ini berkenaan dengan OUV tersebut adalah :

1. Mengamati beberapa bangunan yang penting dan unik yang ada di Kota Lama Semarang dari aspek historisnya.

2. Mengamati beberapa bangunan yang unik dari aspek arsitekturnya mencakup profil, gaya dan langgam arsitektur menurut jamannya.

3. Mengamati keunikan kawasan Kota Lama sebagai satu kesatuan kawasan cagar budaya yang layak ditetapkan sebagai kawasan cagar budaya berperingkat nasional dan warisan budaya dunia.

4. Mengamati lingkungan perkampungan lama yang namanya masih ada yang menunjukkan kebersamaan hidup di kota dari berbagai etnik dan profesi kota praindustri

5. Merekomendasikan beberapa prinsip pelestariannya sesuai dengan Undang-undang Nomor 11 Tahun 2010 Tentang Cagar Budaya dan kriteria OUV yang ditetapkan UNESCO.

Hal penting yang harus dilakukan untuk pengusulan kepada UNESCO untuk menetapkan suatu situs atau kawasan sebagai warisan dunia adalah adanya "Outstanding Universal Values" (OUV), berdasarkan "the Convention Concerning the Protection of the World Cultural and Natural Heritage 1972".

Lebih dari 200 kota-kota tua telah ditetapkan oleh UNESCO sebagai world heritage city, sayangnya belum ada satupun yang ada di Indonesia. Dalam kesempatan ini Pemerintah Indonesia akan mengusulkan kepada UNESCO untuk nominasi sebagai Warisan Budaya Dunia yaitu kepada tiga kota tua yang ada di Indonesia, Kota Tua Jakarta, Kota Tua Sawah Lunto, dan Kota Lama Semarang yang sebelumnya telah dimasukkan ke dalam tentative list of world heritage. Artinya ketiga kota tua ini didorong untuk berbenah diri di bidang konservasi dan menonjolkan OUV yang merujuk pada ketentuan- 
ketentuan internasional.

Dari uraian di atas maka tulisan ini berfokus untuk mencari, mencermati dan mengkaji OUV yang ada di Kota Lama Semarang sesuai kriteria-kriteria yang ditetapkan oleh UNESCO, mencakup aspek-aspek keunikan dan keistimewaan serta model pelestarian yang dilakukan.

\section{B. Metode Penelitian}

Heuristik merupakan salah satu metode utama yang digunakan dalam penelitian ini, yaitu mengumpulkan sumber-sumber primer yang berupa pengumpulan petapeta kuno dan yang lainnya yang berupa berita surat kabar sebagai sumber sejarah. Di samping itu tentu saja dilakukan observasi untuk mengetahui keberadaan dan kondisi bangunan maupun artefak di Kota Lama Semarang. Kemudian studi pustaka juga dilakukan untuk memperoleh data-data sekunder, yang berupa tulisan sejenis, teori maupun data-data yang diperlukan. Baik data dari sumber primer maupun sekunder diklasifikasikan dan dihubung-hubungkan satu dengan yang lainnya sebagai bagian dari analisis untuk mencapai kesimpulan.

\section{Pembahasan}

\section{A. Aspek Historis}

Bukti yang mengawali Kota Lama Semarang adalah adanya loji (benteng) VOC di Semarang terlihat pada Peta $P A A N$ van het Fort en Omleggende Cituatie van Samarang yang menggambarkan situasi Semarang tahun 1695. Loji digambarkan terletak di seberang Timur Kali Semarang. Di sebelah Barat loji, di seberang sungai terdapat Negorij (kampung Melayu sekarang) yang dikelilingi oleh persawahan. Dari arah loji terdapat jalur jalan ke arah Timur (Demak) dan ke Selatan (Kartasura).

Pada pertengahan abad ke-18, benteng Semarang ini dirobohkan diganti dengan banteng kota lama untuk menampung penduduk yang lebih besar. Setelah Kompeni menerima penyerahan Semarang dari Kerajaan Mataram di Yogyakarta pada tahun 1753, nampaknya tekad mereka untuk mengembangkan Semarang menjadi kota besar cukup kuat. Tekad Kompeni untuk mengembangkan Kota Lama terlihat pada peta Plan of Platte Grond van Samarang met het Dies Environs op een Afstand. Inti dari perencanaan disini adalah untuk memperluas loji yang dirasakan semakin sempit. Sayangnya peta ini tidak mencantumkan angka tahun, sehingga tidak diketahui dengan pasti kapan peta dibuat. Namun jika melihat bahwa de Javanesche Tempel sudah berada di Kauman

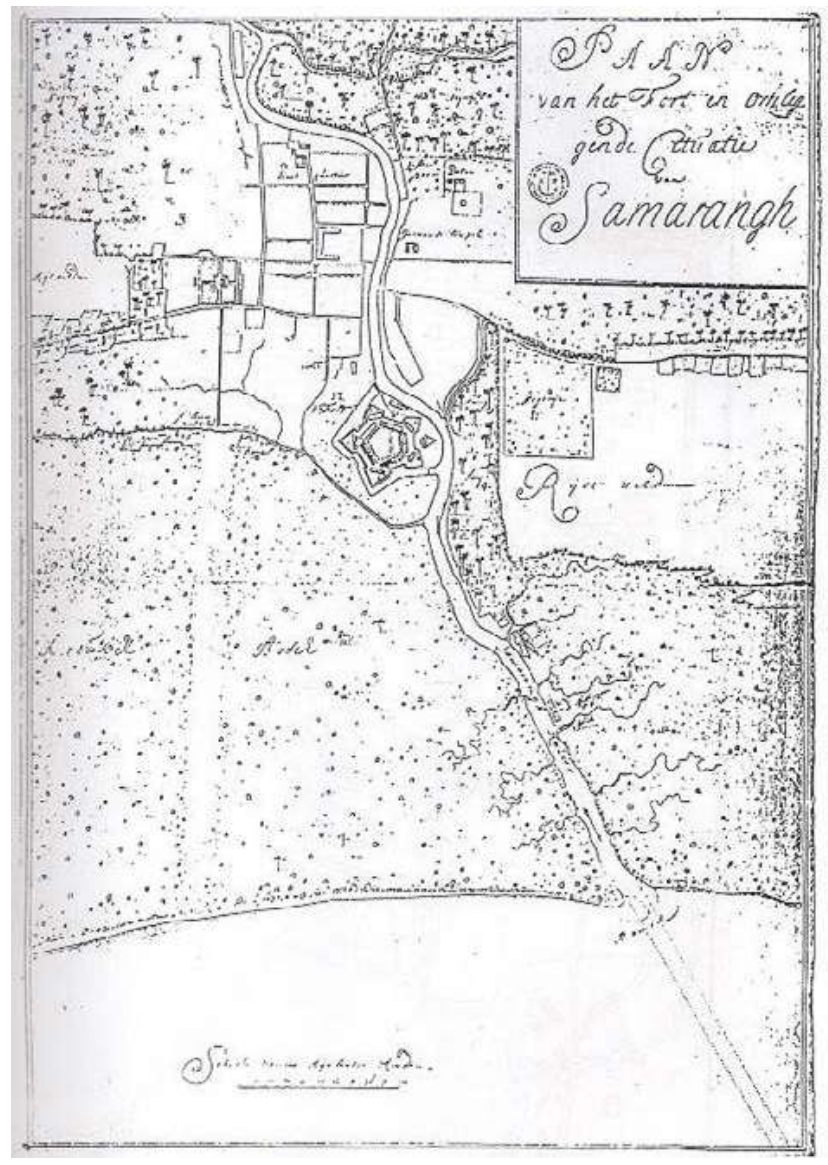

Gambar 1. Peta Kuno Kota Semarang, PAAN van het Fort en Omleggende Cituatie van Samarangh, di sana tampak Benteng VOC (Loji)

(Sumber : Bromer dkk, 1995: 4.)

dan Stadhuis masih berada di Kota Lama, berarti peta itu dibuat akhyir abad ke-18.

Dalam peta terlihat bahwa pembangunan Kota Lama dilakukan dengan memotong bangunan loji, sehingga tinggal bastion di sebelah Barat dan Utara yang letaknya ada di tepi Kali Semarang. Mengingat pembangunan Kota Lama adalah merupakan perluasan dari loji, maka dibangun pula tembok pengaman mengelilingi kompleks pemukiman baru itu. Untuk hubungan ke luar, di sini terdapat tiga pintu gerbang besar, dan beberapa gerbang kecil yaitu :

Ketiga gerbang besar adalah :

a. De Wester Port (pintu gerbang Barat atau Gouvernementspoort) yang berlokasi di Gouvernement Burg atau dikenal dengan Jembatan Berok 
b. De Zuiders Port (pintu gerbang Selatan), berlokasi di sekitar jalan lintas trem, di dekat mulut Jalan Pekojan dan Jalan H. Agus Salim.

c. De Oosters Port (pintu gerbang Timur), berlokasi di ujung Timur Heerenstraat (sekarang persimpangan Jalan Raden Patah dan Jalan MT. Haryono). Enam gerbang kecil atau pos keamanan yaitu :

1. De Hersteller, berlokasi di Jalan Ronggowarsito dan Jalan Pengapon.

2. Ceylon, berlokasi di halaman Gereja Gedangan.

3. Amsterdam, berlokasi di Jalan H. Agus Salim.

4. De Lier, berlokasi di kompleks Kantor Posa lama.

5. De Smits, berlokasi di Boom lama.

6. De Zee, berlokasi di Boom lama (DPU Cipta Karya, 1993).

Di dalam tembok Kota Lama itulah Kompeni membangun sejumlah gedung dan fasilitas perkantoran, paradeplein, stadhuis, ziekenhuis, gevangenis, kazerne, gudang peluru, dan berbagai kantor publik yang lain.

Untuk jalan yang lain, tempat gedung komedi berada disebut Komediestraat (sekarang Jalan Cenderawasih), jalan yang banyak burung layang-layangnya dinamakan Zwaluwstraat (sekarang Jalan Branjangan). Sementara untuk jalan yang ada kebun bunganya disebut Bloemenstraat (sekarang Jalan Kedasih). Toponim lain adalah terkait dengan nama tokoh seperti Van den Burgstraat (sekarang Jalan Perkutut) dan Hoogendorpstraat (sekarang Jalan Kepodang)(Priyanto, 2000).

Dalam pengembangan Kota Lama nampaknya Belanda lebih berorientasi pada nama jalan. Pemberian nama-nama jalan di Kota Lama ini terkesan improvitatif dan lebih menekankan pada aspek fungsional. Nampaknya Parade Plein (sekarang taman dekat Gereja Blendhuk) waktu itu menjadi sentrum, dan Heerenstraat (sekarang Jl. Letjen Soeprapto) merupakan jalur utama di kawasan tersebut.

Untuk jalan di tepi tembok keliling diberi nama sesuai lokasinya, misalnya untuk jalan di tembok Barat disebut Westerwalstraat (Jalan Mpu Tantular), jalan di tembok Utara dinamakan Noorderwalstraat (Jalan Merak), jalan di tembok Timur dinamakan Oosterwalstraat (Jalan Cenderawasih) dan untuk jalan di tembok Selatan disebut Zuiderwalstraat (Jalan Sendowo).

Yang menarik ialah adanya jalan yang diberi nama Kortademstraat, yang artinya nafas pendek. Dinamakan demikian karena ternyata di sini adalah tempat untuk mengeksekusi tawanan (sekarang Jalan Meliwis). Jalan yang lain adalah Konijnenstraat (Jalan Cenderawasih). Jalan yang lain ialah Hoofdwachtstraat, karena di sini ditempatkan markas pasukan pengawal (sekarang Jalan Kutilang), jalan untuk gudang perbekalan dan amunisi disebut Pakhuisstraat. Fasilitas yang lain ialah rumah sakit di Noorderwalstraat, sementara di sisi timur terdapat Artileriewerkplaats dan di dekat pintu gerbang selain pos penjagaan, juga terdapat bangunan panti sosial. Bangunan yang lain adalah Landraad dan Raad van Justitie.

Pada tahun 1782 rumah sakit dipindah agak ke Timur dan bekas gedungnya kemudian dipakai untuk Sekolah Pelayaran (Marineschool). Oleh sebab itu jalannya lalu diberi nama Marinestraat (sekarang Jalan Merpati). Ketika pada tahun 1794 dibangun Gereja Blenduk, jalan di belakangnya lalu diberi nama Achterkerkstraat, yang artinya jalan belakang gereja (sekarang Jalan Garuda). Tahun 1797 dibangun jalan tembus dari Pecinan ke Kota Lama. Karena jalan itu menuju gereja, orang lalu menamakannya Kerkstraat (sekarang Jalan Suari). Untuk jalan yang menuju makam orang menyebutnya Kerkhofstraat (sekarang Jalan Perkutut), sedangkan untuk jalan ke arah pantai berpasir disebut Zeestrand (sekarang Jalan Mpu Tantular) (Priyanto, 2000). 


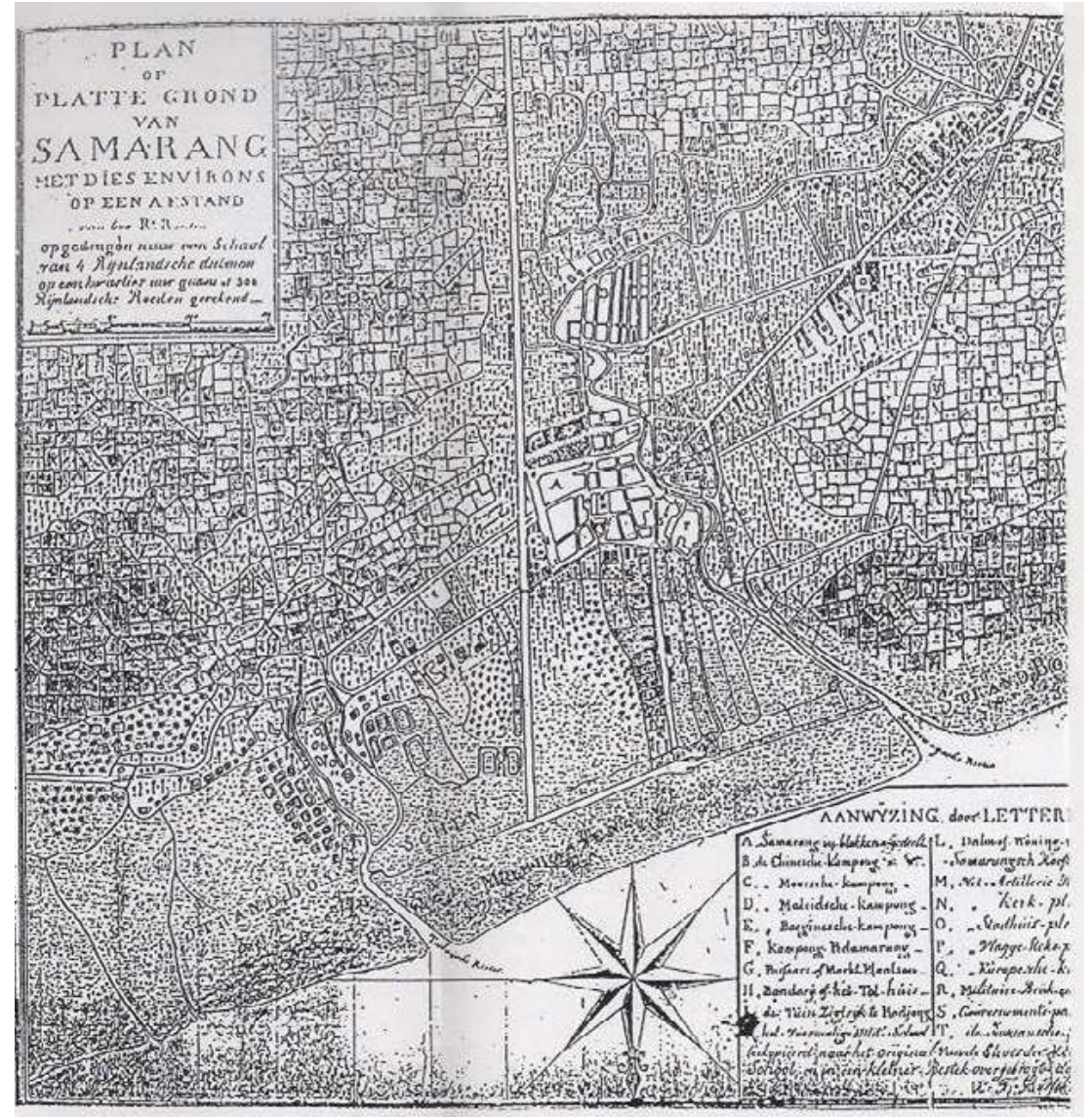

Gambar 2. Peta Kuno Kota Semarang, Plan of Platte Grond van Semarang

(Sumber : Bromer dkk, 1995: 15.)

Keterangan :

A. Pembagian Kota Semarang dalam blok-blok

B. Kampung Cina terletak di sebelah selatan Kota Lama, di tepi barat Kali Semarang

C. Kampung Arab, terletak di bekas Kampung Cina, di sebelah timur K. Semarang, di tenggara Kota Lama

D. Kampung Melayu, di sebelah barat Kali Semarang, di sebelah utara Kota Lama

E. Kampung Bugis, terletak di sebelah utara bastion/pos Hersteller

F. Kampung Pedamarang, di sebelah utara Kampung Cina, di sebelah selatan tembok Kota Lama, di tepi barat Kali Semarang

G. Pasar, ada 4 lokasi, satu pasar di ujung tenggara barak militer di sebelah selatan benteng Kota Lama, di sebelah timur Kali Semarang. Tiga pasar yang lainnya di sebelah barat Kali Semarang, pertama di sebelah barat bastion/pos de ljzer, kedua di utara Kampung Melayu, ketiga di sebalah barat Kampung Pedamarang.

H. Batas dari Gerbang Tol, terletak di sebelah tepi barat Kali Semarang, di utara benteng Kota Lama

I. Taman Bojong, terletak di ujung Jalan Bojong, sebelah selatan Simpang Lima

K. Sekolah Militer, terletak di sebelah barat Jembatan Berok

L. Dalem, tempat kediaman Bupati Semarang, terletak di sebelah barat Kali Semarang, di sebelah barat Kampung Pedamarang, di sebelah barat pasar

M. Barat Artileri, terletak di Parade Plein, di sebelah utara Gereja Blendhuk

N. Taman Gereja, terletak di sebelah utara Gereja Blendhuk

O. Taman Balai Kota, terletak di sebelah timur Gereja Blendhuk

P. Lapangan Tiang Bendera, terletak di sebelah timur Kali Semarang, di sebelah barat bastion/pos de Zee dan bastion/ pos de Smits, di bekas lokasi Benteng Vijhoek

Q. Kuburan Eropa, di sebelah timur Kali Semarang, di timur laut benteng Kota Lama

R. Barak militer dan kandang kuda, terletak dei sisi timur Kali Semarang, di sebelah selatan benteng Kota Lama

S. Gudang-gudang milik pemerintah, terletak di dalam benteng kota, di antara bastion de Smits dan bastion de Zee

T. Masjid, terletak di sisi barat Kali Semarang, di sebelah selatan benteng Kota Lama

Sejalan dengan rencana pertahanan terhadap serangan Inggris, maka Gupernur Jenderal Daendels pada awal abad ke-19 di Jawa membangun Jalan Pos Anyer-Penarukan. Di Semarang jalan ini melewati Bojong, menembus Kota Lama terus ke Timur jurusan Demak/Jepara. Untuk pembuatan jalan pos itu, sebagian tembok Kota Lama terpaksa di korbankan. Namun pada tahun 1811 pemerintah Hindia Belanda terpaksa melepaskan Jawa karena kalah berperang melawan Inggris (Djoenoed, 1984).

$$
\text { Memasuki tahun } 1900 \text { perkembangan }
$$

Semarang jelas mengarah ke kota metropolitan dengan 
heterogenitas penduduknya yang cukup kompleks. Pelapisan sosial terjadi bukan antar etnik, bahkan secara internal pada masing-masing etnik stratifikasinya juga berjalan tajam. Kira-kira pada tahun 1900 wanita Eropa mulai berdatangan ke Jawa dan sejak itu masyarakat Eropapun tumbuh secara eksklusif. Mereka mengembangkan solidaritas baru dan menuntut otonomi terhadap pemerintah Hindia Belanda. Hindia Belanda tidak lagi menjadi tempat pelarian bagi kelas bawah, tetapi sebaliknya diisi oleh anak-anak golongan menengah keluarga Eropa yang berpendidikan baik.

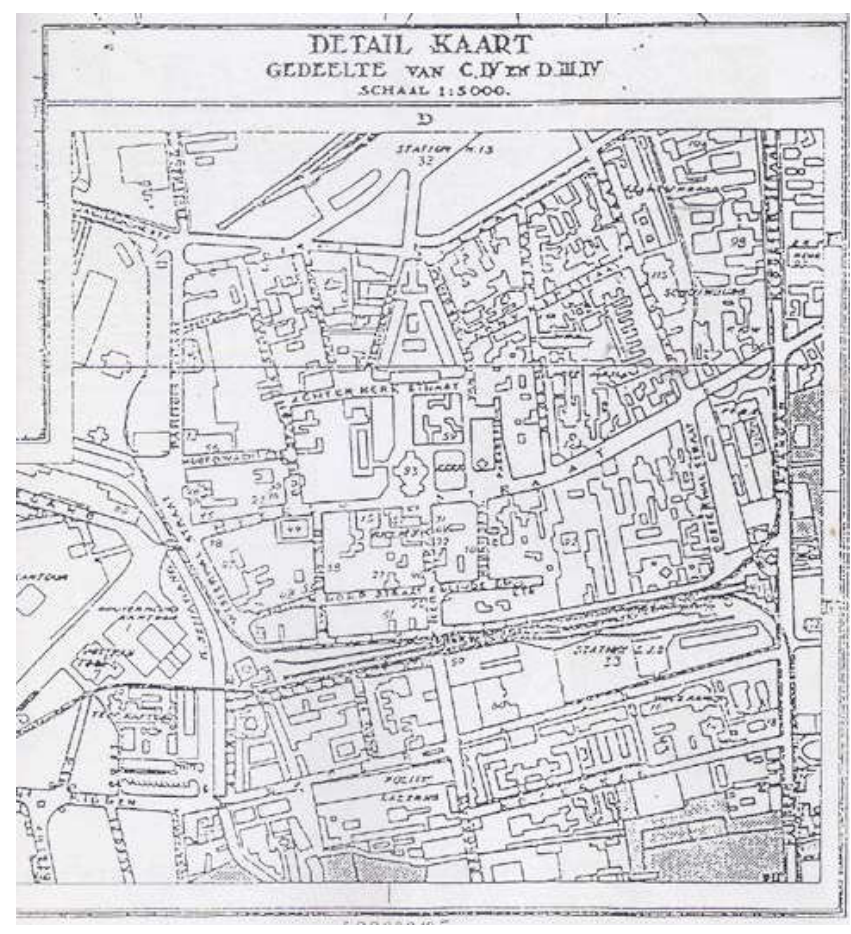

\section{B. Kota Pusaka Warisan Dunia}

Kota Pusaka Warisan Dunia merupakan kota yang ditetapkan UNESCO yang memiliki Outstanding Universal Value (OUV) berdasarkan "the Convention Concerning the Protection of the World Cultural and Natural Heritage 1972", yaitu :

- Merupakan konvensi yang menyediakan kerjasama internasional dalam melestarikan dan melindungi pusaka warisan budaya dan alam seluruh dunia.

- Pusaka warisan dunia didaftar UNESCO berdasar proteksi legal yang kuat dari masingmasing pemerintah negara dimana pusaka itu ada.

- Diputuskan dalam Sidang Umum United Nations Educational, Scientific and Cultural Organization (UNESCO) Paris, 17/10 - 21/11 1972, sesi ke-17. Banyak pihak menyatakan konvensi ini merupakan salah satu produk terbaik yang dikeluarkan UNESCO. (UNESCO, 2005)
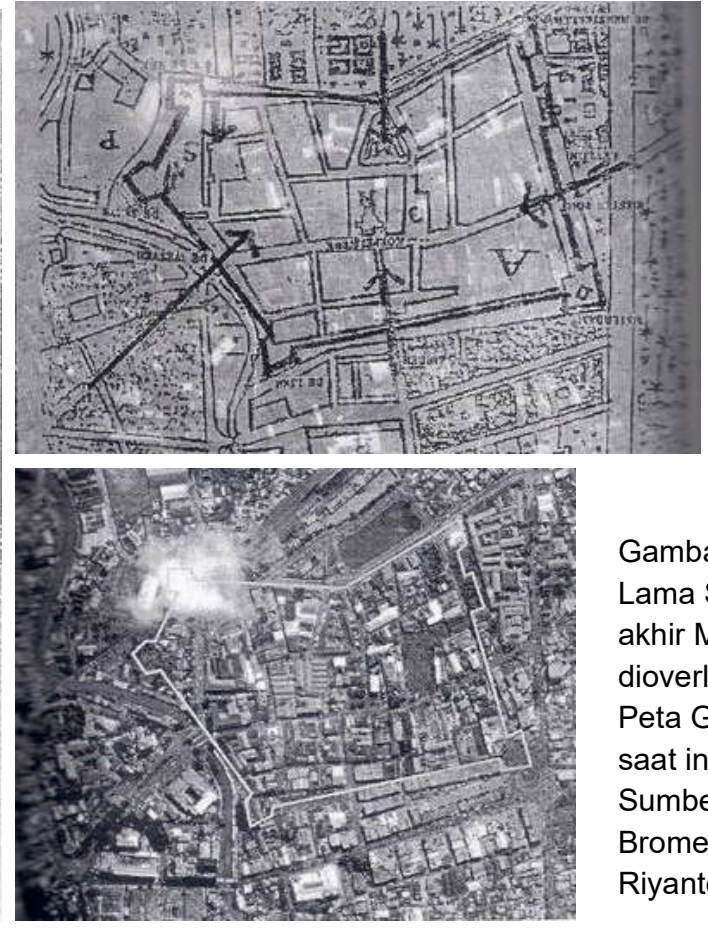

\section{Gambar 3. Peta Kota Lama Semarang di akhir Masa Kolonial dioverlaykan dengan Peta Google kondisi saat ini Sumber : Bromer dkk, 1995 Riyanto, Sugeng, 2011}

Untuk menominasikan dan penetapan Kota Lama Semarang sebagai Kota Pusaka Warisan Dunia (The World heritage city) oleh UNESCO, kota tersebut perlu menyandang 1 (satu) atau lebih dari 10 kriteria nilai-nilai universal luar biasa (OUV) yang dikeluarkan UNESCO, antara lain (Operational Guidelines for the Implementation of the World Heritage Convention, 2012) :

1. Merupakan mahakarya kecerdasan kreatif manusia

2. Menampilkan pertukaran nilai-nilai luhur manusia, dalam rentang waktu atau dalam lingkup budaya dunia, dalam arsitektur, teknologi, seni monumental, perencanaan kota atau rancangan lansekap;

3. Menyandang peran sebagai jejak yang unik atau istimewa dari suatu tradisi budaya atau peradaban baik yang sudah lenyap maupun yang masih ada;

4. Menjadi contoh utama suatu tipe bangunan, gubahan arsitektur atau teknologi, atau lansekap yang menggambarkan babakan yang penting dalam sejarah manusia 
5. Menjadi contoh sebuah pemukiman tradisional manusia, penggunaan lahan, atau laut yang merepresentasikan suatu kebudayaan, atau interaksi manusia dengan lingkungan terutama ketika telah menjadi rentan di bawah dampak perubahan

6. Berkaitan baik secara langsung maupun tidak langsung dengan peristiwa atau tradisi yang hidup, dengan gagasan, dengan kepercayaan, dengan karya seni dan sastra yang memiliki nilai penting universal yang menonjol;

7. Merupakan fenomena alam yang luar biasa atau kawasan dengan keindahan alam serta estetika yang luar biasa dan penting;

8. Merupakan contoh yang luar biasa yang mewakili tahapan utama sejarah perkembangan bumi, termasuk catatan kehidupan, proses geologi signifikan yang sedang berlangsung dalam pengembangan bentang alam, atau geomorfik yang signifikan atau fitur fisiografi lainnya;

9. Merupakan contoh yang luar biasa mewakili proses ekologis dan biologis yang signifikan yang sedang berlangsung dalam evolusi dan pengembangan darat, air tawar, ekosistem pesisir dan laut dan komunitas tumbuhan dan hewan;

10. Mengandung habitat alam yang paling penting dan signifikan untuk konservasi in-situ keanekaragaman hayati, termasuk spesies terancam yang mengandung nilai universal luar biasa dari sudut pandang ilmu pengetahuan atau pelestarian.

Untuk dapat disebut memiliki nilai universal yang unggul atau menonjol, suatu objek pusaka harus memenuhi syarat integritas atau ke-otentikan dan harus memiliki sistem perlindungan dan pengelolaan untuk menjamin kelestariannya di masa datang. Integritas ditunjukkan melalui :

- Adanya semua elemen yang diperlukan untuk mengungkapkan nilai universal yang unggul

- Adanya ukuran yang memadai untuk menjamin tampilnya secara utuh ciri-ciri dan proses yang menunjukkan nilai pentingnya

- adanya pelindungan terhadap efek negatif pembangunan atau pengabaian

Adapun keaslian/keotentikan pusaka ditunjukkan melalui

- bentuk dan rancangan,

- bahan dan substansi, guna dan fungsi,
- tradisi, teknik dan sistem pengelolaan

- lokasi dan setting

- bahasa dan bentuk warisan budaya tak bendawi lainnya

- semangat dan perasaan

- faktor internal dan eksternal lainnya

Pelindungan dan pengelolaan ditunjukkan melalui:

- Kondisi pusaka yang baik

- Dampak penurunan kondisi terkendali

- Proporsi tertentu pusaka menampilkan totalitas nilai yang terungkap

- Hubungan dengan fungsi lingkungan yang dinamis yang penting bagi karakter utama objek tersebut haruslah terjaga

Sebagai pertimbangan lain yang cukup penting dalam rangka penetapan :

- Indonesia belum memiliki kota yang menyandang predikat Kota Pusaka Dunia yang ditetapkan UNESCO.

- Kota Surakarta merupakan satu-satu kota di Indonesia yang menjadi anggota Organization of the World Historic Cities

- Kota Yogyakarta satu-satunya kota di Indonesia yang menjadi anggota the League of The World Historic Cities yang berkedudukan di Kyoto.

OUV (Outsanding Universal Values) merupakan salah satu kriteria penilaian yang digunakan UNESCO untuk penetapan warisan dunia. Agar menyandang warisan dunia suatu pusaka harus memenuhi syarat integritas dan/ atau keotentikan serta sistem pelindungan (konservasi) dan pengelolaan untuk menjamin kelestariannya.

\section{Aspek Arsitektural}

Perkembangan Kota Lama Semarang sejak kemunculannyadimasa lampau hingga sekarang, sebenarnya juga menunjukkan perkembangan gaya arsitektur seperti di Eropa. Pada akhir abad ke-17 ketika VOC datang di Semarang, mereka membangun Benteng De Vijhoek (loji) sebagai tempat tinggal dan bertahan orang-orang asing tersebut. Selama hampir seratus tahun VOC bertahan di Kota Semarang, kemudian benteng tersebut dirobohkan dan diperluas menjadi tembok Kota Lama Semarang pada akhir abad ke-17. Namun demikian pertengahan abad ke18 benteng Kota Lama akhirnya juga dirobohkan, sebab tidak lagi dapat menampung pemukiman penduduk, dan akhirnya Kota Lama Semarang tumbuh berkembang tanpa tembok kota hingga awal abad ke-19. 
Seperti di Eropa, arsitektur benteng mengawali gaya arsitektur kota lama yang kemudian dilanjutkan dengan munculnya gaya arsitektur neo-klasik seperti yang berkembang di Eropa pada abad ke-18-19. Pada pertengahan abad ke-18 di Eropa dikenal sebuah gerakan arsitektur yang disebut arsitektur neo-klasik dan eklektis, sebagai dampak dari kejenuhan akan ornamen, maka pada periode ini arsitektur dikembalikan pada kodratnya seperti pada masa sebelum periode romantik. Gaya ini merupakan gaya anti rokoko yang dapat ditemukan pada beberapa gaya arsitektur Eropa, contohnya pada arsitektur Palladian di Georgia, Inggris, juga di Paris, Berlin, dan Roma (Sumalyo, 2005).

Perkembangan arsitektur di Eropa dan dunia internasional dari akhir abad ke-18 yang didominasi oleh gaya neo-klasik dan selama abad ke-19 yang tumbuh gaya modernisme, merupakan suatu pergerakan yang signifikan dalam bidang arsitektur barat. Di sini mulai tampak adanya kejenuhan akan gaya-gaya klasik, karena pada masa-masa sebelumnya arsitektur hanya dianggap sebagai suatu bentuk dari seni dan perasaan. Namun kemudian terjadi suatu revolusi yang dikenal dengan revolusi industri di Inggris yang memulai dunia dengan era baru yaitu era pabrikasi. Di samping itu, perkembangan politik di Eropa berdasarkan konvensi Wina (1815) juga telah membentuk banyak negara kerajaan baru di sana. Dalam hal ini para arsitek mendapat peluang untuk membangun istana, gereja, perlemen, museum, universitas, perpustakaan, gedung konser, gedung opera, green house, yang kebanyakan diciptakannya dengan kecenderungan menerapkan gaya klasikisme, meskipun secara konstruksi menerapkan bahan bangunan hasil industri. Arsitektur Eropa pada abad itu bersifat eklektik dengan banyak bangunan elitnya yang terjebak dalam gaya dari masa lalu yang disebut neoklasikisme itu (Sumalyo, 2005: 60-65).

Arsitektur pada era neo-klasik tersebar di berbagai benua dengan ciri khas dari masing-masing negara induk di Eropa yang sedang berdaulat. Di Indonesia, arsitektur gaya ini dibawa oleh orang-orang Belanda yang ketika itu berkuasa. Mereka merasa berkepentingan untuk membuat bangunan-bangunan sebagai fasilitas penunjang kegiatan mereka selama di Indonesia. Oleh karena itu, arsitektur klasik maupun neo-klasik yang diterapkan pada bangunan tersebut adalah masih mengikuti gaya arsitektur atau langgam yang sedang berlaku di negara asalnya. Gaya arsitektur ini biasanya diterapkan pada bangunan yang bersifat pemerintahan, sebab pada masa itu mereka mulai menguasai dan memonopoli perdagangan di Indonesia. Di samping itu mereka juga ingin memiliki kekuasaan atas kewilayahan di Indonesia, dan kemudian mereka merasa perlu juga untuk membuat suatu pemerintahan sebagai landasan yang kuat untuk menguasai suatu wilayah. Namun seiring dengan proses adaptasi dan interaksi dengan masyarakat pribumi, maka semakin beragam pula bangunan yang dibuat dengan aneka ragam bentuk dan fungsinya (Sumalyo, 2005: 60-65).

Gaya neo klasik ini di Indonesia sering juga disebut dengan 'gaya imperium', karena dimanfaatkan untuk melegitimasi kekuasaan kolonial itu sendiri. Di Eropa gaya ini lahir karena dilatari oleh munculnya banyak kerajaan pada abad ke-18. Penggunaan gaya ini di Indonesia diawali pada masa Gubernur Jenderal Masekal Herman Willem Daendels (1808-1811) yang pertama kali memperkenalkan gaya imperium ini untuk menandai pembentukan negara kolonial di Hindia Belanda, mengikuti ciri arsitektur yang sama di Berlin, Washington DC, dan di kotanya sendiri Paris. Gaya ini memperlihatkan keteraturan, karena memang didasarkan pada sebuah sistem yang jelas. Tidak ada yang lebih sempurna untuk menggambarkan sebuah pemerintah yang menginginkan kebijakan serba tegas dan penampilan monumental. Dapat dikatakan bahwa penampilan monumental dan kesan penting yang diemban bangunan pemerintahan dalam keseluruhan tata letak kota menjadikan gaya imperium sebagai simbol kewibawaan, keteraturan dan kemakmuran (Kusno, 2009: 169-186). Gereja Blenduk dan beberapa bangunan di kota lama yang dibangun pada abad ke-19 menunjukkan gaya neo-klasik yang dibangun di kota lama.

Di dalam perencanaan yang lebih detail, elemenelemen kota yang berbentuk bangunan memiliki bentuk arsitektur bernilai simbolik dan estetik yang juga tidak akan lepas dari struktur sosial maupun budaya masyarakat. Seperti dikatakan oleh Peter Nas (1993: 14-16), bahwa nilai simbolik akan dapat berfungsi (function of symbols) sebagai media komunikasi kelompok (masyarakat), untuk legitimasi kepemimpinan (leadership) dan untuk mengontrol masyarakat. Simbol juga mempunyai suatu emanasi estetik dan mempunyai kekuatan yang berpengaruh bagi masyarakat. Aspek dinamika simbol (the 
dynamics of symbols) tercermin di dalam arsitektur bangunan kolonial moderen yang lebih banyak menggunakan gaya art deco di Indonesia pada awal abad ke-20.

Art deco adalah gaya hias yang lahir setelah Perang Dunia I dan berakhir sebelum Perang Dunia II dan banyak diterapkan dalam berbagai bidang, misalnya eksterior, interior, mebel, patung, poster, pakaian, perhiasan dan lain-lain dari 1920 hingga 1939, yang mempengaruhi seni dekoratif seperti arsitektur, desain interior, dan desain industri, maupun seni visual seperti misalnya fesyen, lukisan, seni grafis, dan film. Gerakan ini dalam pengertian tertentu adalah gabungan dari berbagai gaya dan gerakan pada awal abad ke-20, termasuk konstruksionisme, kubisme, modernisme, baubaus, art nouveau, dan futurisme, bahkan neoklasik. Meskipun banyak gerakan desain mempunyai akar atau maksud politik atau filsafat, art deco murni bersifat dekoratif, dan pada masa itu gaya ini dianggap anggun, fungsional, dan ultra moderntertidur (Sumalyo, 2005: 132-174).

Art deco merepresentasikan modernisasi dunia yang begitu cepat. Ketika gaya ini sudah menyebar luas dan sudah ada di dunia "fasbion" di Amerika dan Eropa, kata - kata "Art Deco" sendiri sebenarnya tidak dikenal, tetapi lebih dikenal sebagai gaya modernistik atau 1925 style sering menjadi sebutannya. Kata art deco sendiri mulai muncul dari tahun 1925 di sebuah konferensi l'Exposition Internationale des Arts Decoratifs Industriels et Modernes yang diadakan di Paris, Perancis.Kata art deco termasuk terminologi yang baru pada saat itu, diperkenalkan pertama kali pada tahun 1966 dalam sebuah katalog yang diterbitkan oleh Musée des Arts Decoratifs di Paris yang pada saat itu sedang mengadakan pameran dengan tema "Les Années 25". Pameran itu bertujuan meninjau kembali pameran internasional l' Expositioan Internationale des Arts Décoratifs Industriels et Modernes. Sejak saat itu nama art deco dipakai untuk menamai seni yang saat itu sedang populer dan modern. Munculnya terminologi itu pada beberapa artikel semakin membuat nama art deco eksis. Art deco semakin mendapat tempat dalam dunia seni dengan dipublikasikannya buku "Art Deco" karangan Bevis Hillier di Amerika pada tahun 1969.

Dalam perjalanannya art deco dipengaruhi oleh berbagai macam aliran modern, juga mengambil ideide desain kuno misalnya dari Mesir, Siria dan Persia. Meskipun art deco terlihat seperti ultra modern, sebenarnya dapat ditelaah kembali ke zaman kuburan Mesir kuno. Secara khusus, penemuan kubur Raja Tut pada tahun 1920 membuka pintu lebar terhadap gaya ini. Garis yang tegas, warna-warna yang kuat dan fitur-fitur arsitektural yang berbentuk zig-zag ditambahkan ke dalam objekobjek yang diletakkan di dalam kubur untuk menghibur dan mencerahkan raja yang sedang tertidur (Sumalyo, 2005: 132-174).

Aspek-aspek simbolik yang dapat dimaknai dari bangunan-bangunan kolonial abad ke-20 yang umumnya bergaya art deco sudah menunjukkan kebebasan berekspresi dari para perancangnya, yang tidak lagi terkekang oleh politik-etnosentris Eropa. Aspek-aspek lokal baik lingkungan maupun budaya juga telah diakomodasi, sejalan dengan politik etis maupun politik desentralisasi yang dicanangkan oleh pemerintah kolonial pada masa itu. Oleh karena itu, simbol-simbol dalam arsitektur tidak lagi untuk melegitimasi rezim, tetapi lebih berdomain seni-budaya. Artinya mitos-mitos politik-ideologis tidak lagi mendominasi dalam tataran pemaknaan, seperti yang terjadi pada abad ke-19, tetapi cenderung turun dari tingkatan mitos ke tingkatan konotasi dan estetis. Di samping bangunan yang bergaya arsitektur art deco, pada masa ini muncul pula gaya bangunan Indo-Belanda, yang sering pula disebut bangunan indis (Soekiman, 1996).

Menurut Charles Prosper Wolff Schoemaker, guru besar arsitektur Technische Hogeschool Bandoeng (ITB) tahun 1924-1938, ciri bangunan berlanggam arsitektur Indo-Eropa (indis) ini relatif mudah dikenali. Sosok bangunan umumnya simetris, memiliki ritme vertikal dan horizontal relatif sama kuat. Konstruksi bangunan disesuaikan dengan iklim tropis, terutama pada pengaturan ruang, pemasukan pencahayaan sinar matahari, dan perlindungan terhadap curah hujan. Pencarian bentuk arsitektur yang responsif terhadap kondisi iklim dan geografis setempat inilah yang membawa pada seni bangunan baru, yakni Arsitektur Indis (Sumalyo, 1993: 69-108).

Di Kota Lama Semarang, bangunan benteng saat ini memang sudah tidak ada lagi karena sudah dirobohkan, tinggal fondasi-fondasinya saja yang kini sedang ditelusuri kembali oleh Balai Arkeologi Yogyakarta. Namun bangunan-bangunan yang berciri neo-klasik dari abad ke-19 dan berciri art deco dari abad ke-20 ditemukan di kota lama. Gereja Blenduk mewakili 
gaya neo-klasik abad ke-19, sedangkan Restoran Ikan Bakar Cianjur dan Gereja Gedangan mewakili gaya art-deco abad ke-20. Hal ini menunjukkan cukup lama Pemerintah Kolonial Belanda ada di Indonesia, Semarang khususnya, maka tahapan perkembangan arsitektur Eropa ada di kota lama, dan Kota Lama Semarang ini sering mendapat julukan "Little Amsterdam". Kota Amsterdam sendiri sekarang sudah masuk sebagai world heritage city, semoga demikian halnya Kota Lama Semarang. Keunikan sejarah kawasan dan arsitektur Kota Lama Semarang ini memang memiliki nilai-nilai universal luar biasa (OUV), namun tentu yang lebih dipentingkan dalam mewujudkan Kota Lama Semarang sebagai world heritage city adalah kemauan berbagai pihak untuk melakukan pelestarian, perlindungan dan pengelolaan yang baik.

Dari peta-peta Semarang kuno yang dapat diamati dan juga fenomena-fenomena yang masih tersisa di sekitar kota lama menunjukkan adanya perkampunganperkampungan penduduk Kota Semarang tempo dulu saat-saat Semarang masih berbentuk kota pra industri (Sjoberg, 1960). Saat itu penduduk Kota Semarang tinggal secara berkelompok antara lain menurut profesi, jabatan, etnik, dan agamanya, dalam perkampungan antara lain di Kampung Kauman, Kampung Batik, Kampung Pecinan dan Kampung Arab. Ini menunjukkan salah satu kriteria OUV nomor 2 yang ditetapkan oleh UNESCO yaitu adanya pertukaran nilai-nilai luhur manusia, dalam rentang waktu atau dalam lingkup budaya dunia, dalam arsitektur, teknologi, seni monumental, perencanaan kota atau rancangan lansekap. Khususnya aspek etnisitas ini menjadi hal yang sangat menarik karena di Kota Semarang tempo dulu telah terjadi integrasi antar etnik dan antar bangsa yang terwadahi dalam satu kota.

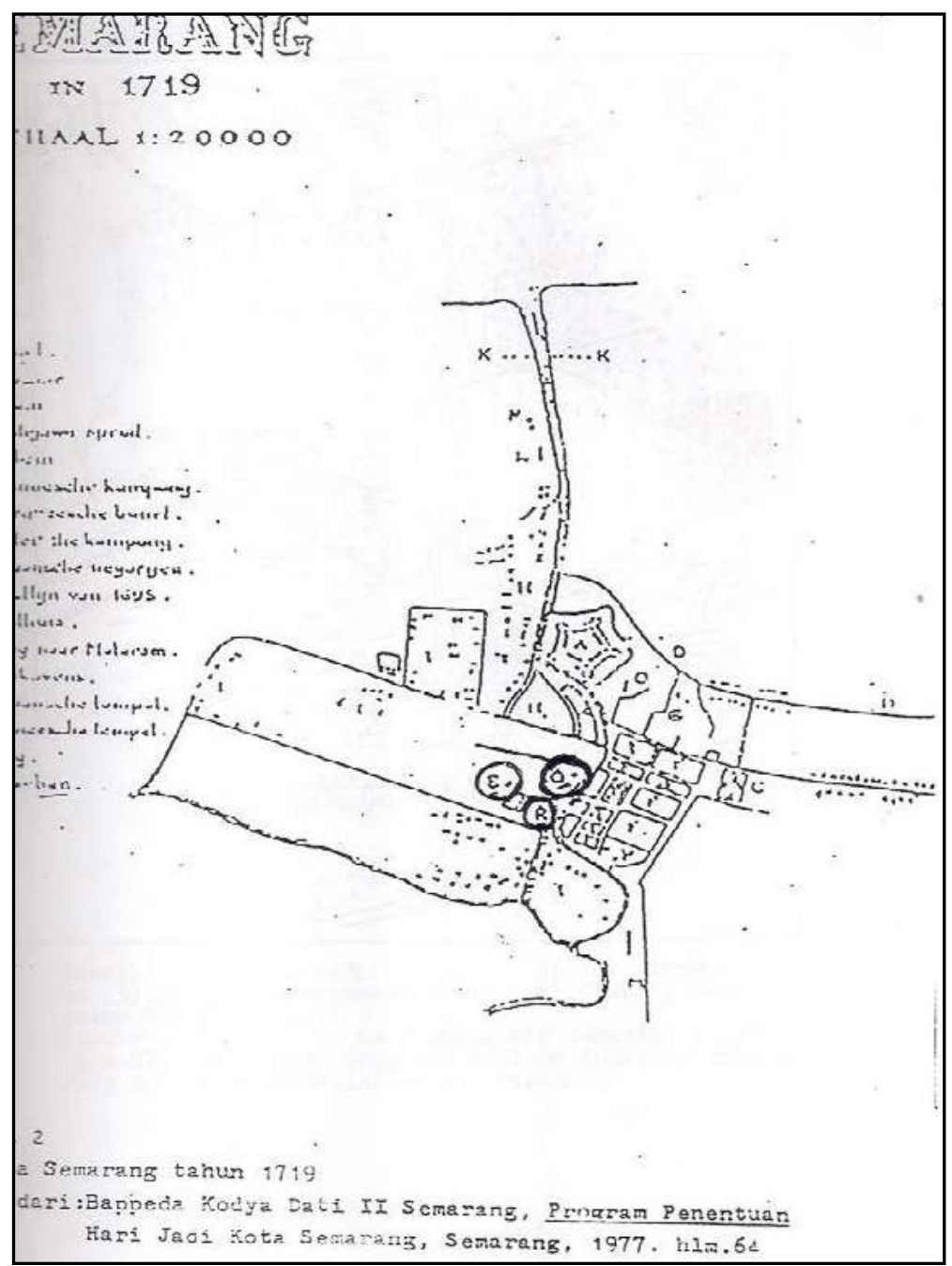

Gambar 4. Peta Kota Lama Semarang Tahun 1719 Sumber : Bappeda Semarang, 2011

Keterangan :

- Benteng VOC, terletak di sebelah timur Kali Semarang, dengan lima bastion.

- Pasar, terletak di tenggara Benteng VOC, di sebelah timur Kali Semarang

- Taman, terletak di sebelah timur Kampung Cina

- Kanal Kaligawe, di sebelah utara benteng

- Dalem, di sebelah barat K. Semarang, di sebelah selatan benteng

- Kampung Cina, di sebelah timur K. Semarang, di sebelah tenggara benteng

- Pemukiman Eropa, di sebelah tenggara benteng, di utara Kampung Cina

- Kampung Melayu, terletak di tepi timur dan barat Kali Semarang, di sebelah barat laut benteng

- $\quad$ Garis pantai pada tahun 1695

- Gerbang Tol lalu lintas air, di sebelah barat Kali Semarang, di utara benteng

- Jalan menuju Mataram, melewati Kampung Cina dan Kampung Jawa ke selatan

- Tobong kapur, di sebelah barat K. Semarang, di utara gerbang tol

- Masjid, di sebelah barat laut Dalem

- Klenteng Cina, di sudut tenggara Kampung Cina

- Gala

- Kampung Jawa, terletak di pertemuan Kali Semarang, Kali Kripik dan Kali Kreo, tepatnya di sebelah selatan Kampung Cina, di sebelah tenggara Dalem

- Paseban, di timur laut Dalem 
Oleh karena itu, dalam rangka memunculkan OUV di Kawasan Kota Lama Semarang, peninggalanpeninggalan sejarah dan budaya baik yang bersifat tangible maupun intangible di kawasan ini harus dikonservasi dan dikembangkan dengan baik dan sedapat mungkin harus dihidupkan lagi untuk mewujudkan adanya pertukaran nilai luhur dan integrasi etnik. Sejak beberapa tahun ini, Pemerintah Kota Semarang sudah menghidupkan lagi industri kerajinan batik Kampung Batik, dan Komunitas Cina juga membangun Pasar Semawis di Kampung Pecinan yang sangat ramai saat hari suci Imlek. Di pusat kota lama, pemerintah kota juga sudah mulai serius mengelola kawasan ini dengan melakukan konservasi kawasan dan bangunannya, serta mengadakan eventevent khusus pada waktu-waktu tertentu. Masyarakat juga sudah mulai ikut berperan dengan mambangun restoran dan kafe-kafe, serta berjalan cindera mata yang antik. Kegiatan pariwisata dapat menjadi media untuk membangun citra kawasan ini, walaupun nantinya akan membesar saat kawasan ini sudah menjadi warisan dunia.

Kota Penang dan Georgetown di Malaysia dapat menjadi perbandingan, sebab kota ini telah menjadi kota warisan budaya dunia sejak tahun 2008. Kota ini juga berisi bangunan-bangunan tua milik pemerintah kolonial yang dikelilingi oleh pemukiman penduduk dari beberapa etnik, seperti etnik melayu, etnik cina dan etnik India. Keunikan ini merupakan dianggap sebagai OUV, sebagai landasan pokok UNESCO menetapkan kawasan ini sebagai warisan budaya dunia. Akhirnya saat kawasan kota tua di Malaysia ini juga menjadi pusat kegiatan pariwisata di sana, sebab pemerintah Malaysia dan masyarakat benar-benar serius untuk menampilkan keunikan sejarah dan budaya kawasan yang kemudian menjadi OUV itu (Omar, Shida Irwana, 2013: 88-96).

\section{Kesimpulan}

Dari uraian di atas dapat dikemukakan beberapa hal sebagai kesimpulan :

1. Saat ini Kota Lama Semarang sudah masuk ke dalam daftar warisan dunia oleh UNESCO (tentative list of world heritage), yang artinya mempunyai kesempatan untuk berbenah diri sebaik-baiknya untuk kemudian apabila sukses akan dinominasikan sebagai warisan budaya dunia sebagai khususnya world heritage city.
2. Di samping aspek manajemen terhadap warisan sejarah di Kota Semarang ini sebagai syarat penetapan warisan dunia, maka adanya OUV (Outstanding Universal Values) juga menjadi syarat penetapan itu. Minimal satu dari 10 kriteria OUV yang ditetapkan oleh UNESCO, dalam hal ini Kota Lama Semarang dapat menjadi contoh utama suatu tipe bangunan, gubahan arsitektur atau teknologi, atau lansekap yang menggambarkan babakan yang penting dalam sejarah manusia.

3. Di samping itu Kota Lama Semarang juga menampilkan pertukaran nilai-nilai luhur manusia, dalam rentang waktu atau dalam lingkup budaya dunia, dalam arsitektur, teknologi, seni monumental, perencanaan kota atau rancangan lansekap. Hal ini tampak dari bersatunya banyak perkampungan etnik di kawasan sekitar Kota Lama Semarang yang menunjukkan adanya persatuan antar etnik dan antar bangsa di bawah pemerintahan VOC.

4. Apabila Kota Lama Semarang dapat meraih penghargaan world heritage city dari UNESCO, tentu merupakan perolehan penghargaan yang sangat membanggakan, sebab Jawa Tengah memperoleh satu lagi penghargaan dunia ini di samping yang sudah ada yaitu Candi Borobudur, Candi Prambanan, Situs Manusia Purba Sangiran, serta Wayang, Batik, dan Keris. 


\section{Daftar Pustaka}

Arbi, Yunus, 2013, Pengelolaan Lansekap Budaya "Subak" Bali, Makalah dari Direktorat Internalisasi Nilai dan Diplomasi Budaya Kementerian Pendidikan dan Kebudayaan.

Bappeda Kodya Dati II Semarang, 1977, Program Penentuan Hari Jadi Kota Semarang

Bromer, dkk, 1995, Semarang Beeld van een Stad, Netherlands :Asia Major, hal. 15.

Kusno, Abidin, 2009, "Gaya Imperium yang Hidup Lagi Setelah Mati", in Nas, Peter JM (ed), Masa Lalu dalam Masa Kini Arsitektur di Indonesia, Jakarta : Gramedia.

Nas, Peter, JM. , 1993, Urban Symbolism, Leiden, New York, Koln : E J Brill

Omar, Shida Irwana at.al., 2013, “George Town, Penang as a World Heritage Site: The Stakeholders' Perceptions",PSU-USM International Conference on Humanities and Social Sciences, Procedia - Social and Behavioral Sciences 91 ( 2013 ) 88 - 96.

Operational Guidelines for the Implementation of the World Heritage Convention, 2012, UNITED NATIONS EDUCATIONAL, SCIENTIFIC AND CULTURAL ORGANISATION INTERGOVERNMENTAL COMMITTEE FOR THE PROTECTION OF THE WORLD CULTURAL AND NATURAL HERITAGE.

Riyanto, Sugeng, 2011, “Gambaran Kota Semarang Tahun 1719 dan 1800 Berdasarkan Peta Lama, International Seminar Proceedings, Urban Heritage Its Contribution to the Present, Published by Department of Archaeology, Faculty of Cultural Sciences, Gadjah Mada University.

Sjoberg, Gideon, 1960, The Pre-industrial City : Past and Present, New York-London : The Free Press.

Sumalyo, Yulianto, 1993, Arsitektur Kolonial Belanda di Indonesia, Yogyakarta : Gadjah Mada University Press.

2005, Arsitektur Modern Akhir Abad XIX dan Abad XX, Yogyakarta : Gadjah Mada University Press.
Priyanto, Supriyo, 2000, Tinjauan Historis Perkembangan Struktur Kota Semarang Kuno: Studi Tentang Toponim, Laporan Akhir Penelitian Bappeda Kota Semarang.

Soekiman, Djoko, 1996, Kebudayaan Indis dan Gaya Hidup Masyarakat Pendukungnya di Jawa (Abad XVIII Sampai Medio Abad XX).Disertasi pada Fakultas Sastra, UGM Yogyakarta.

Undang Undang RI No. 11 Tabun 2010 tentang Cagar Budaya, di dalam himpunan peraturan perundang undangan RI tentang Benda Cagar Budaya, Depdikbud, 1997.

The United Nations Educational, Scientific and Cultural Organization, 2005,Basic Texts of the 1972 World Heritage Convention,Place de Fontenoy, 75352 PARIS 07 SP 